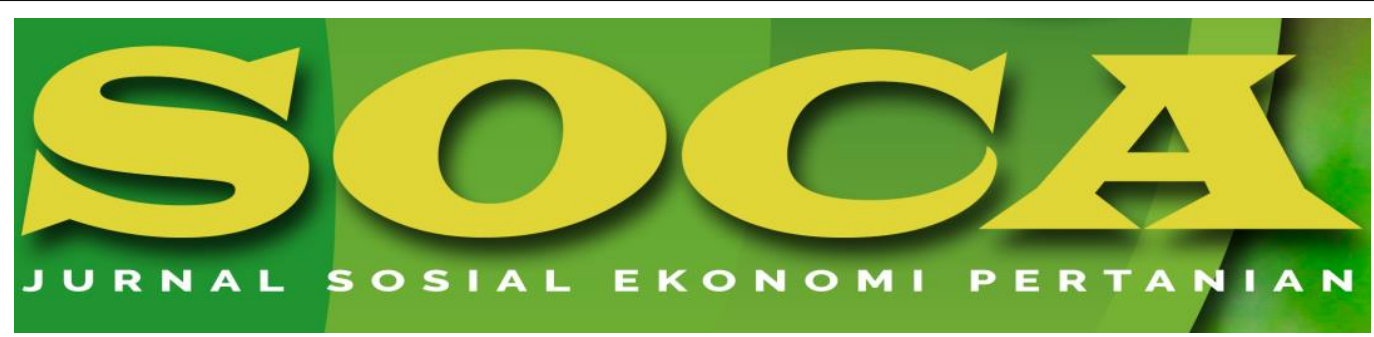

https://ojs.unud.ac.id/index.php/soca

\title{
The Role of Coffee Plantation in the Kerinci Regency Regional's Economy
}

\author{
Suandi, Dompak Napitupulu and Endy Effran \\ Department of Agribusiness, Faculty of Agriculture, Jambi University \\ Email: suandi_pertanian@unja.ac.id \\ Mobile: 081394313880
}

Submitted: January 27th, 2019; Revised: March 19th, 2020; Accepted: April 12th, 2020

\begin{tabular}{ll}
\hline Keywords: & Abstract \\
LQ; coffee & The main indicator in economy development was the role and \\
plantation; & of the sub-sectors that had a major role and contribution in economy \\
regional & development was coffee plantations. To determine the role of coffee \\
economy & plantations on the community's economy in Kerinci Regency, Jambi \\
& Province, therefore the research aims were (1) to determine the role \\
of coffee plantations on income and employment, (2) to determine the \\
contribution of coffee plantations to income and employment, and (3) \\
to determine the ratio of coffee plantation growth to income and \\
employment. The research was conducted in Kerinci Regency in \\
2015 with 6 months research period. The research data were \\
sourced from secondary data, which was time series data from \\
2005-2013. Data were analyzed using the Location Qoutient (LQ) \\
approach, and Shift-share. The results showed that coffee \\
plantations in Kerinci Regency were the base sector. The analysis \\
results obtained that coffee plantations played a role as the main \\
driver of the Kerinci Regency's economy because it had a high \\
income and employment. During the period of nine years 2005-2013, \\
economic growth, income and employment of coffee plantation in \\
Kerinci Regency showed a positive ratio value though it was \\
fluctuated.
\end{tabular}

How to Cite (APA 6th Style):

Suandi, Napitupulu, D., \& Effran, E. (2020). The Role of Coffee Plantation in the Kerinci Regency Regional 's Economy. SOCA: Jurnal Sosial Ekonomi Pertanian, 14(3), 499-510.

https://doi.org/https://doi.org/10.24843/SOCA.2020.v14.i03.p1 1 


\section{INTRODUCTION}

The data released by the Indonesian Coffee Industry and Export Association (AEKI, 2017), Indonesia was the fourth largest coffee producer in the world after Brazil, Vietnam and Colombia. According to the International Coffee Organization Report (International Coffee Organization, 2019), Indonesia exported coffee to more than 50 countries. One of Indonesia's coffee production centers was the Jambi Province (Central Bureau of Statistics Indonesia, 2018). The potential areas which were the centers of coffee production in Jambi Province including Kerinci Regency, Sungai Penuh City, Merangin Regency and West Tanjung Jabung Regency. The types of coffee plants varied from robusta coffee, arabica and liberika coffee (Plantation Agency of Jambi Province, 2018). One of the biggest coffee production centers in Jambi Province was Kerinci Regency.

The latest data showed that the area of coffee plantations in Kerinci Regency was 7,573 ha or $30 \%$. The famous coffee from the Kerinci Regency of Jambi Province was arabica coffee which has received a certificate from the Ministry of Agriculture's Law and Human Rights, with an area of 654 ha (Ministry of Agriculture, 2018). To remember that Arabica coffee has a profitable prospect for farmers and regions (Suandi et al, 2013). Arabica coffee was an export commodity that was in high demand of the world market, so farmers in Kerinci were trying to grow Arabica coffee to meet consumer demand both in the national and international markets, especially in European countries.

The highly consumer interest especially European countries, so that coffee was an important part of creating the center of economic growth. According to Sugiyanto and Sukesi (2010), that the creation of centers of economic growth can be started from several dynamic sectors and were able to provide high output ratios in certain regions. These outputs can have wide effects (spread effects) and multiple effects on other sectors and the wider region, especially the economic development. The market power will guarantee equilibrium (balance) in the spatial distribution of the economy and the trickle-down effect or center down process. The implementation of the creation of a growth center must be followed by a trickle-down effect (dropping downward effect) and spread effect through a harmonious activity between the growth center and the resource base in the rural area, so that the growth center's activities affected the surrounding area which will also be able to grow.

The coffee commodity development required a study of technical aspects, including through the aspects of cultivation and production, upstream to downstream (Syahyuti, 2007). The processed coffee industry can then be marketed, but required contributions of thoughts and ideas from various parties ranging from the coffee farming community, the government, research institutions and the business world (Jambi Provincial Government, 2018). On the other hand, coffee farmers were still faced with the problem of limited knowledge of skills, access to marketing and access to capital which was the mutual concern.

Open an access for local entrepreneurs post-harvesting or coffee processing hoping that the added value of the coffee commodity can be enjoyed by the local community, increasing economic value and welfare. Welfare can be distinguished through two measurement approaches, which were: objective welfare and subjective welfare. Objective welfare measurement seen that the level of welfare of a community can be measured by an average value and was measured by certain standards (such 
as: economic, social and other measures). In other words, the level of welfare of a community with other communities was measured by the same standard (Panggabean, 2011). Based on the measurement of the farmers' welfare, it was very necessary to strengthen or empower their abilities. Accelerate the rate of economic growth, so that in turn it can strengthen the economic structure of the region or community (Astiartie, 2010).

The measurement of regional economy development through strengthening superior sectors both comparative superior and competitive superior sectors. The data that released by the Directorate General of Plantations (2014), one of the superior sectors of the Kerinci Regency was coffee plantations. To support the achievement of the superior sector development, statistical data were needed that can describe one sector, planning for other sectors.

According to Arianti (2011) and Sukirno, (2011), mapping the area for business processes in the plantation sub-sector as well as the agricultural sub-sector business, of course, can place the business appropriately, seen from the regional typology. It was expected that the development of an area or sector which becomes the first priority will be able to attract the development of other sectors and in turn will be able to increase regional economic growth. That was one of the basic frameworks of analysis that can be used for planning and evaluating economic development outcomes. Also it was the importance of examining the role and contribution and impact of each sector on the improvement or economic development of a region. To determine the role of coffee plantations on income and employment in the Kerinci Regency of Jambi Province, the research aims were: (1) to determine the contribution of coffee plantations to the income and employment in the Kerinci Regency of Jambi Province, and (2) to determine the coffee plantation growth trend to the income and employment in the Kerinci Regency, Jambi Province.

\section{RESEARCH METHODS}

The research design was documentation. The research was conducted in Kerinci Regency, Jambi Province in 2015. The time needed to performed the research from preparation to research reporting was 6 (six) months. Research location that chosen with the consideration that this region was one of the coffee's production centers. The data used in this research were secondary data, which were series data from 2005-2015. The research data was obtained from the relevant agency offices: the Jambi Provincial Plantation Office, the Kerinci Regency Plantation Office, the Jambi Central Bureau of Statistics Report (BPS) and the Kerinci Central Bureau of Statistics. This research measured the level of community and business income so that the variables which studied were: (a) Gross Regional Domestic Income (PDRB) of the Kerinci Regency and PDRB of the Jambi Province, (b) income of the Kerinci Regency coffee plantation and income of the Jambi Province coffee plantation, and (c) the number of residents working in the Kerinci Regency coffee plantations and Jambi Province coffee plantations. To answer about the role and contribution of coffee plantations in the economy of the Kerinci Regency region were analyzed descriptively, quantitatively, using a single frequency table and a cross table. Then proceed to analyze the time series data for 2005-2013 to the contribution and the ratio of growth to the economy of the Kerinci Regency, which was analyzed using the Location Qoutient (LQ) approach, contribution analysis, and Shift-share approach. 
According to (Sugiyanto \& Sukesi, 2010), there were four methods that can be used to identify key sectors/bases in the economy, which were: (a) a sector was considered key if it has backward linkages and forward linkages which was relatively high, (b) a sector was considered as a key sector if, it produced relatively high gross output so that it was able to maintain a relatively high final demand, (c) a sector was considered as a key sector if, it was able to generate net foreign exchange earnings which were relatively high, and (d) a sector was considered key sector if, capable of creating relatively high jobs. The research output produced a portrait of economic development and welfare of the community in the research area. Then found a sectoral-based regional development model and coffee business jobs, with standards for achieving research objectives. The model of improving the economic welfare of the community and its problems, as well as obtained various determinants of economic development that developed in the research area, both in terms of their role and function aspects of economic development. The discovery of a model of economic development strategy was in order to realize the improvement of economic welfare of the community.

\section{RESULTS AND DISCUSSION}

\section{The Analysis of the Coffee Plantations Role in Research Areas}

Regionally, the economy of the Kerinci Regency region was divided into two sectors, they were the basic sector (basic activities) and non-basic sectors (non-basic activities). Each sector had a different activity base. Such as basic activities, was activities aimed at exporting goods and services to places outside the society economic boundaries. Then, non-basic activities were activities that provided goods needed by people who live within the society economic boundaries itself, so that this region did not export finished goods. (Glasson: Dewi Sondari, 2007). The non-basic sector was intended to meet local needs, so it was strongly influenced by the level of income of the local community, and cannot develop beyond the regional economic growth (Tarigan, 2012). There was also another possibility, non-basic income and job opportunities were determined by income and job opportunities on a sector basis. Therefore, the growth of an area was determined by how the region's performance to meet the demand for goods and services that came from outside the region/country.

The basic sector was indicated by the value of Location Quotient (LQ> 1), while non-basic activities were activities that provided goods and services. This was certainly needed by people who were in the economic area and from non- basic sector. Then, the non-basic sector can indicate the opposite $(L Q<1)$. Basic activities played a major role in the economy of a region. The greater the export of one region to another, the more regional growth will be developed (Arifin, 2009). The basic sector played a role in regional development, because of the potential to gain large income from exports. The LQ value also indicated a relative benefit convergence, an interregency sector, caused by an abundance of natural resources that was imperfect mobility.

According to Sugiyanto and Sukesi, (2010), there were four methods that can be used to identify key sectors/basics in the economy, which were: (a) a sector was considered key if it has backward linkages and forward linkages which was relatively high, (b) a sector was considered as a key sector if, it produced relatively high gross output so that it was able to maintain a relatively high final demand, (c) a sector was 
considered as a key sector if, it was able to generate net foreign exchange earnings which were relatively high, and (d) a sector was considered key sector if, capable of creating relatively high job opportunities.

\section{The LQ Analysis of Coffee Plantation with Income Indicator}

The role of coffee plantations in improving the income of Kerinci Regency community through LQ calculation, obtained the level of coffee plantations role on community income, seen from 2005-2015, whether experienced an increased or decreased in production. The calculation results showed that the LQ value had a value $>1$. The LQ value of coffee plantations in Kerinci Regency, Jambi Province, through the time series from 2005-2013, which was the Basic sector, was seen in Table 1.

Table 1. LQ Value of Coffee Plantation with Income Indicator Based on Constant Prices.

\begin{tabular}{cccccccc}
\hline Year & $\begin{array}{c}\text { PDRB } \\
\text { Kerinci-Regency } \\
\text { (vt) }\end{array}$ & $\begin{array}{c}\text { Income- } \\
\text { Kerinci } \\
\text { Coffee } \\
\text { Farmers (vt) }\end{array}$ & vi/vt & $\begin{array}{c}\text { PDRB } \\
\text { Jambi-Province } \\
\text { (Vt) }\end{array}$ & $\begin{array}{c}\text { Income- } \\
\text { Jambi- } \\
\text { Province } \\
\text { Coffee } \\
\text { Farmers (Vi) }\end{array}$ & Vi/Vt & LQ \\
\hline 2005 & 84.765 .197 & 2.758 .275 & 0,033 & 11.707 .827 .680 & 47.651 .400 & 0,004 & 8,00 \\
2006 & 89.269 .898 & 2.511 .600 & 0,028 & 13.342 .433 .730 & 68.436 .960 & 0,005 & 5,49 \\
2007 & 94.531 .006 & 11.180 .208 & 0,118 & 13.724 .627 .430 & 57.655 .020 & 0,004 & 28,15 \\
2008 & 100.075 .244 & 21.659 .100 & 0,216 & 12.291 .371 .550 & 62.538 .426 & 0,005 & 42,54 \\
2009 & 105.959 .700 & 12.333 .060 & 0,116 & 19.458 .840 .650 & 79.059 .510 & 0,004 & 28,65 \\
2010 & 112.198 .800 & 29.426 .430 & 0,262 & 19.407 .458 .840 & 96.415 .770 & 0,005 & 52,79 \\
2011 & 118.586 .400 & 32.416 .200 & 0,273 & 39.203 .466 .640 & 105.959 .160 & 0,003 & 101,14 \\
2012 & 126.301 .500 & 32.946 .120 & 0,261 & 47.187 .604 .280 & 108.385 .200 & 0,002 & 113,57 \\
2013 & 134.525 .000 & 34.603 .500 & 0,257 & 86.151 .481 .210 & 114.936 .750 & 0,001 & 192,81 \\
\hline & & & & Average & & &
\end{tabular}

Source: Central Bureau of Statistics of Kerinci Regency, Jambi Province (2015)(processed).

In Table 1, it showed that the LQ value of coffee plantations from year to year had increased although slightly fluctuating, with an average LQ of 63.68. The LQ value in the period of 2005-2006 was decreased, but in the period of 2007-2008 there was a significant increase in the average of 28.15 and 42.54 . But a year later there was a decreased again due to a decrease in the income of Jambi Province community (PDRB) so that the LQ value had decreased. Then there was a significant increase between year 2011-2013, respectively 101.14, 113.57 and 192.81. This means that the development of Jambi Province's PDRB economy had increase, LQ value $>1$. These findings were in line with research conducted by Lina Marlina et al (2017), that the coffee plantation sector contributed $6.49 \%$ to the West Lampung Regency PDRB. The large contribution of coffee to regional income was supported by research by Ida Ayu Listia Dewi and I Made Sudarma (2020), the results of a case study in Bali showed that the contribution of coffee plantations to farmers' income was Rp. $22,820,376$ per year or around $69.07 \%$. The large income of coffee farmers nowadays was supported by the application of new technologies in the development of farming 
and competitiveness, such as the use of technology in marketing and the passion of modern entrepreneurship (technopreneurship) (Ni Wayan Rainy Priadarsini Sukiada and Anak Agung Ayu Intan Parameswari, 2020). Other factors that strongly supported the cultivation of coffee plants in Indonesia, was the presence of environmental factors (land and agro-climate), capital and production results were the most decisive factors for farmers' interest in coffee farming (Joachim et al., 2018).

\section{The LQ Analysis of Coffee Plantation with Labor Indicators}

The need for labor in the Kerinci Regency was quite good, in accordance with its role, that Jambi can be said to be a sufficient supply or producer of coffee for imports. According to Ardila (2012) that, labor (Man Power) was usually the people in the community area, which was preferred to work or in the economic process was the major portion of the community that can be included in the economic process (Tan Goan Tiang: Mantra, 2000). Generally, the measurement of the Kerinci Regency condition as a plantation worker can be linked to the productive age limit between 15-64 years.

The role of coffee plantations in increasing labor enrollment in Kerinci Regency with the number of the Location Qoution (LQ), obtained the level of coffee plantations role in labor enrollment. To see the effect of coffee plantations on labor LQ values whether $>1$ in the Kerinci Regency coffee plantation with Labor Indicators data for the years 2005-2013, comparison of Jambi Province, > 1-can be seen in Table 2.

Table 2. LQ Value in Coffee Plantation with Labor Indicator.

\begin{tabular}{|c|c|c|c|c|c|c|c|}
\hline Year & $\begin{array}{c}\text { Labor- } \\
\text { Kerinci } \\
\text { (vt) }\end{array}$ & $\begin{array}{c}\text { Labor- } \\
\text { Coffee- } \\
\text { K } \\
\text { (vi) }\end{array}$ & (vi/vt) & $\begin{array}{c}\text { Labor- } \\
\text { Jambi } \\
\text { (Vt) }\end{array}$ & $\begin{array}{c}\text { Labor- } \\
\text { Coffee-J } \\
\text { (Vi) }\end{array}$ & (Vi/Vt) & LQ \\
\hline 2005 & $65.688,0$ & $3.954,0$ & 0,060 & 506.682 & 27.818 & 0,055 & 1,096 \\
\hline 2006 & $68.480,3$ & $3.007,0$ & 0,044 & 528.759 & 27.696 & 0,052 & 0,838 \\
\hline 2007 & $69.973,5$ & $7.777,0$ & 0,111 & 563.706 & 27.692 & 0,049 & 2,262 \\
\hline 2008 & $74.617,1$ & $8.078,0$ & 0,108 & 599.912 & 27.678 & 0,046 & 2,346 \\
\hline 2009 & $113.793,8$ & $7.950,0$ & 0,070 & 619.615 & 25.357 & 0,041 & 1,707 \\
\hline 2010 & $79.366,2$ & $7.616,0$ & 0,096 & 604.167 & 25.413 & 0,042 & 2,281 \\
\hline 2011 & $77.757,7$ & $7.798,0$ & 0,100 & 619.080 & 26.056 & 0,042 & 2,383 \\
\hline 2012 & $76.278,7$ & $8.054,0$ & 0,106 & 592.335 & 26.622 & 0,045 & 2,349 \\
\hline 2013 & $112.138,8$ & $8.080,0$ & 0,072 & 636.855 & 26.699 & 0,042 & 1,719 \\
\hline
\end{tabular}

Source: Plantation Agency of Jambi Province (2015)(processed)

In Table 2, it showed that, the LQ value based on the labor approach in coffee plantations in Kerinci Regency had increased from year to year with an average LQ of 1.89. However, the LQ value for the period 2005-2006 was decreased by 1.096 and by 0.838 . During the period of 2007-2008 there was a significant increase, but there was a decrease in 2009. The value of LQ increased again in 2010-2012. LQ value decreased in 2012 amounted to 1,719. This might not have a significant effect on the increased in the labor of Jambi Province. The calculation of LQ value of coffee plantations in Kerinci Regency was always greater than number 1 (LQ> 1). This indicated that the coffee plantations in the Kerinci Regency during the period of 
2005-2013 as a driver in the labor enrollment in the Kerinci Regency Jambi Province. Considering that the coffee plantation sector was able to recruit more than $20 \%$ of the total labors (Lina Marlina et al, 2017).

\section{Coffee Plantation's Contribution to the Regional Economy}

The results of the 2005-2013 time series data, the contribution of coffee plantations to regional income can be described through the level of contribution or role given by coffee plantations to PDRB. The level of coffee plantations ability to create value-added was very dependent on the development and amount of production, and costs. The data on the contribution of coffee plantations in the Kerinci Regency period of 2005-2013 with income indicators were shown in Table 3.

Table 3. Data of Coffee Plantation Contribution with Income Indicator.

\begin{tabular}{|c|c|c|c|c|c|}
\hline \multirow[b]{2}{*}{ Year } & \multirow[b]{2}{*}{$\begin{array}{l}\text { Production } \\
\text { (1) }\end{array}$} & \multirow[b]{2}{*}{$\begin{array}{l}\text { Price } \\
(2)\end{array}$} & \multirow[b]{2}{*}{$\begin{array}{c}\text { NPB } \\
(3) \\
(1 \times 2)\end{array}$} & \multicolumn{2}{|c|}{ Intermediate Cost } \\
\hline & & & & $\begin{array}{c}\text { Ratio } \\
\text { (4) }\end{array}$ & $\begin{array}{c}\text { Value } \\
(5) \\
(3 \times 4)\end{array}$ \\
\hline 2005 & 533 & 7.500 & 3.997 .500 & 0,31 & 1.239 .225 \\
\hline 2006 & 455 & 8.000 & 3.640 .000 & 0,31 & 1.128 .400 \\
\hline 2007 & 1976 & 8.200 & 16.203 .200 & 0,31 & 5.022 .992 \\
\hline 2008 & 3650 & 8.600 & 31.390 .000 & 0,31 & 9.730 .900 \\
\hline 2009 & 1986 & 9.000 & 17.874 .000 & 0,31 & 5.540 .940 \\
\hline 2010 & 3877 & 11.000 & 42.647 .000 & 0,31 & 13.220 .570 \\
\hline 2011 & 3915 & 12.000 & 46.980 .000 & 0,31 & 14.563 .800 \\
\hline 2012 & 3979 & 12.000 & 47.748 .000 & 0,31 & 14.801 .880 \\
\hline 2013 & 4012 & 12.500 & 50.150 .000 & 0,31 & 15.546 .500 \\
\hline
\end{tabular}

Source: Plantation Agency of Jambi Province (2015) (Processed).

In Table 3, it showed that coffee production in Kerinci Regency from year to year tended to increase except in 2008, from 3,650 tons in 2009 to 1,986 tons or decreased by 45.58 percent. In 2010-2013 it continued to experience a significant increase. Theoretically, an increase in coffee production from year to year had a positive impact on the income of Jambi Province PDBR, and indirectly affected the income of coffee farmers.

Coffee farmers' income of Kerinci Regency showed a positive thing where every year has increased even though it has not been able to boost the welfare of farmers. However, the low price of coffee was inversely related to farming costs. The calculation results obtained that the cost (ratio) was only around $31 \%$ of the total cost of farming costs will be profitable, if the income was higher than the cost of production. However, seen from the current condition of farmers, farmers' income in Kerinci Regency was relatively stable from year to year.

The calculation results obtained that the level of coffee plantations contribution in the Kerinci Regency gave a positive contribution to farmers' income. Overall, the average contribution from farmers' coffee plantations was $3.05 \%$. The contribution of coffee plantations in Kerinci Regency was relatively the same as the trend of production development in 2005-2013 (Table 4). 
Table 4. Coffee Plantation Contribution with Income Indicators, Year 2005-2013.

\begin{tabular}{cccc}
\hline Year & NTB** $^{*}$ & PDRB & Kont (\%) \\
\hline 2005 & 4.953 .802 & 84.765 .197 & 0,06 \\
2006 & 4.107 .376 & 89.269 .898 & 0,05 \\
2007 & 81.388 .544 & 94.531 .006 & 0,86 \\
2008 & 305.452 .951 & 100.075 .244 & 3,05 \\
2009 & 99.038 .762 & 105.959 .700 & 0,93 \\
2010 & 563.817 .649 & 112.198 .800 & 5,03 \\
2011 & 684.207 .324 & 118.586 .400 & 5,77 \\
2012 & 706.760 .166 & 126.301 .500 & 5,60 \\
2013 & 779.656 .975 & 134.525 .000 & 5,80 \\
\hline \multicolumn{4}{c}{ Average } \\
\hline
\end{tabular}

Source: Kerinci Regency Central Bureau of Statistics (2015)

\section{The Contribution of Coffee Plantation to Labor Enrollment}

The results of the 2005-2013 time series data calculations, the contribution of coffee plantations to labor enrollment had a considerable value. The contribution of the Kerinci Regency coffee plantations with labor indicators, in 2005-2013, can be seen in Table 5.

In Table 5 showed that the average contribution of coffee plantations in labor enrollment reached $8.53 \%$. This figure was far greater than the contribution to farmers' income, although it fluctuated from year to year. In 2005, the contribution of coffee plantations in labor was $6.02 \%$. But in 2006 , it decreased to $4.39 \%$, and a year later or in 2007 there was a significant increase that reached $11.11 \%$, and this figure was the value of the largest contribution of coffee plantations to labor. Then, in 2008 and 2009, it continued to experience a decrease. In 2010-2012, it increased again, although not as big as what happened in 2007. This indicated that coffee plantations in Kerinci Regency contributed positively to labor enrollment.

Table.5. Contribution of Kerinci Regency Coffee Plantation to Labor Indicator.

\begin{tabular}{ccccc}
\hline No & Year & $\begin{array}{c}\text { Labor- Total } \\
\mathbf{( 5 1 \% )}\end{array}$ & $\begin{array}{c}\text { Labor- Coffee } \\
\text { Plantation }\end{array}$ & $\begin{array}{c}\text { Contribution } \\
\text { (\%) }\end{array}$ \\
\hline 1 & 2005 & $65.688,0$ & $3.954,0$ & 6,02 \\
2 & 2006 & $68.480,3$ & $3.007,0$ & 4,39 \\
3 & 2007 & $69.973,5$ & $7.777,0$ & 11,11 \\
4 & 2008 & $74.617,1$ & $8.078,0$ & 10,83 \\
5 & 2009 & $113.793,8$ & $7.950,0$ & 6,99 \\
6 & 2010 & $79.366,2$ & $7.616,0$ & 9,60 \\
7 & 2011 & $77.757,7$ & $7.798,0$ & 10,03 \\
8 & 2012 & $76.278,7$ & $8.054,0$ & 10,56 \\
9 & 2013 & $112.138,8$ & $8.080,0$ & 7,21 \\
\hline
\end{tabular}

Source: Kerinci Regency Central Bureau of Statistics (2015)

Information: Labor-Total (51\%) was the total labor in the Agriculture sector. 


\section{Growth Ratio Analysis (Shift-Share)}

The results of the growth ratio analysis (shift-Share) of coffee plantations occurred in the Kerinci Regency of Jambi Province. The income indicator used valueadded data based on the basic constant prices was the same with basic year prices. The same indicator was expected at the time of calculation the value of growth was obtained with the validity of the results that can be accounted for (Tarigan, 2012). To see the growth ratio of coffee plantations in Kerinci Regency in 2005-2013, through the income indicator can be seen in Table 6 .

In Table 6, it showed that the calculation result of shift share analysis was based on income indicators that the average growth ratio of 10.21 , fluctuated from year to year. A very high increase in 2007 was 58.56. This means having a very significant growth ratio value. Each period showed a very significant purification, means that the growth ratio of coffee plantations experienced a low phosphate value. In 2010, the ratio experienced a slight increase compared to 2012-2013 which experienced a drastic decrease. The growth ratio from 2005-2013 had fluctuated as shown in Table.6.

Table 6. Growth Ratio of Coffee Plantation with Income Indicator

\begin{tabular}{|c|c|c|c|c|c|}
\hline \multirow{2}{*}{ Year } & PDRB & \multirow{2}{*}{$\begin{array}{c}\text { Pert. } \\
\text { (r) }\end{array}$} & \multirow{2}{*}{$\begin{array}{l}\text { Coffee- } \\
\text { Income } \\
\text { Kerinci- } \\
\text { Regency }\end{array}$} & \multirow{2}{*}{$\begin{array}{c}\text { Pert. } \\
\text { (r) }\end{array}$} & \multirow{2}{*}{$\begin{array}{l}\begin{array}{c}\text { Ratio } \\
\text { Pert. }\end{array} \\
\text { (Rps) }\end{array}$} \\
\hline & Kerinci-Regency & & & & \\
\hline 2005 & 84.765 .197 & & 2.758 .275 & & \\
\hline 2006 & 89.269 .898 & 5,31 & 2.511 .600 & $-8,94$ & $-1,68$ \\
\hline 2007 & 94.531 .006 & 5,89 & 11.180 .208 & 345,14 & 58,56 \\
\hline 2008 & 100.075 .244 & 5,86 & 21.659 .100 & 93,73 & 15,98 \\
\hline 2009 & 105.959 .700 & 5,88 & 12.333 .060 & $-43,06$ & $-7,32$ \\
\hline 2010 & 112.198 .800 & 5,89 & 29.426 .430 & 138,60 & 23,54 \\
\hline 2011 & 118.586 .400 & 5,69 & 32.416 .200 & 10,16 & 1,78 \\
\hline 2012 & 126.301 .500 & 6,51 & 32.946 .120 & 1,63 & 0,25 \\
\hline \multirow[t]{2}{*}{2013} & 134.525 .000 & 6,51 & 34.603 .500 & 5,03 & 0,77 \\
\hline & \multicolumn{4}{|c|}{ Average } & 10,21 \\
\hline
\end{tabular}

Source: Kerinci Regency Central Bureau of Statistics, (2015)(processed)

Tabel 7. Plantation Growth Ratio with Labor Indicator

\begin{tabular}{cccccc}
\hline Year & $\begin{array}{c}\text { TK- Kerinci- } \\
\text { Regency } \\
\text { (vt) }\end{array}$ & $\begin{array}{c}\text { Pert. } \\
\text { (r) }\end{array}$ & $\begin{array}{c}\text { TK-Coffee-K } \\
\text { (vi) }\end{array}$ & Pert. (r) & $\begin{array}{c}\text { Ratio } \\
\text { Pert. } \\
\text { (Rps) }\end{array}$ \\
\hline 2005 & $65.688,0$ & & $3.954,0$ & & \\
2006 & $68.480,3$ & 4,25 & $3.007,0$ & $-23,95$ & $-5,63$ \\
2007 & $69.973,5$ & 2,18 & $7.777,0$ & 158,63 & 72,75 \\
2008 & $74.617,1$ & 6,64 & $8.078,0$ & 3,87 & 0,58 \\
2009 & $113.793,8$ & 52,50 & $7.950,0$ & $-1,58$ & $-0,03$ \\
2010 & $79.366,2$ & $-30,25$ & $7.616,0$ & $-4,20$ & 0,14 \\
2011 & $77.757,7$ & $-2,03$ & $7.798,0$ & 2,39 & $-1,18$ \\
2012 & $76.278,7$ & $-1,90$ & $8.054,0$ & 3,28 & $-1,73$
\end{tabular}




\begin{tabular}{|c|c|c|c|c|c|}
\hline & $112.138,8$ & 47,01 & $8.080,0$ & 0,32 & 0,01 \\
\hline
\end{tabular}

Source: Plantation Agency of Jambi Province, 2015 (processed).

In Table 6, it showed that the calculation results showed the growth ratio of coffee plantations did not much different from the growth ratio based on income indicators. The average growth ratio was 7.21. In 2007 the growth ratio experienced a significant increase of 72.75 which was quite high. Possibly there was a positive ratio of coffee plantations, due to the increase in gross added-value. So it experienced a change in the growth ratio to total income and labor enrollment which was a positive value.

\section{CONCLUSIONS}

Coffee plantations in Kerinci Regency were the basic sector. The analysis showed that coffee plantations played a role as the main driver of the economy. Coffee plantations in Kerinci regency played a role in the regional development, because coffee plantations had the potential to earn high income and labor. Mathematically, the LQ value of coffee plantations in Kerinci Regency from year to year was always greater than $1(\mathrm{LQ}>1)$. The LQ value also illustrated that coffee plantations in Kerinci Regency during the 2005-2013 period were the economic drivers.

Coffee plantations had an important role in improving the economy in Kerinci Regency. The large role of coffee plantations on the economy and the large contribution of coffee plantations can increase income and labor enrollment.

During the eleven years (2005-2013) the income growth and labor enrollment of coffee plantation workers in Kerinci Regency showed a positive ratio value, although fluctuating. The existence of a positive ratio of coffee plantations is due to the increase in the gross added-value of coffee plantations, so that there will be changes in the amount of income and labor enrollment which has positive value.

\section{RECOMMENDATION}

Coffee plantations in Kerinci Regency were the potential commodities, basic sectors, and had positive growth from year to year. Coffee plantations can increase income and labor enrollment so that it needs to develop commodities and provide added-value for farmers, especially through the development of agribusiness.

\section{REFERENCES}

Ardila, Refika 2012. Analisis Pengembangan Pusat Pertumbuhan Ekonomi di Kabupaten Banjarnegara. Economics Development Analysis Journal, EDAJ 1 (2) (2012). Semarang: http://journal.unnes.ac.id/sju/index.php/edaj

Arianti, Nyayu Neti, 2011. Klasifikasi Subsektor Pertanian Kabupaten/Kota di Provinsi Bengkulu (Pendekatan Tipologi Klassen). Palembang: Proseding SEMIRATA BKS-PTN, Fakultas Pertanian UNSRI. ISBN: 978-979-8389-18-4.

Arifin, Z. . (2009). Analisis Perbandingan Perekonomian Pada Empat Koridor Di Propinsi Jawa Timur. Jurnal Ekonomi Pembangunan, 7(1), 77. https://doi.org/10.22219/jep.v7i1.3585 
Asosiasi Eksportir dan Industri Kopi Indonesia (AEKI), 2017. Statistik Ekspor Kopi Indonesia. Asosiasi Eksportir dan Industri Kopi Indonesia (AEKI). Address: J1. R.P. Soeroso No. 20 Jakarta, 10330, Indonesia.

Astiartie, Tia, 2010. Analisis Kebutuhan Investasi Sektor-Sektor Ekonomi Unggulan dalam Upaya Peningkatan Kesempatan Kerja di Kota Surakarta. (Tidak dipublikasikan), Skripsi. Surakarta: Jurusan Ekonomi Pembangunan Fakultas Ekonomi Universitas Sebelas Maret Surakarta.

Badan Pusat Statistik Indonesia, 2018. Statistik Kopi Indonesia 2017 (Indonesian Coffee Statistics). Badan Pusat Statistik/BPS Statistics Indonesia. ISBN: 978602-438-187-5.

Dewi Sondari, 2007. Analisis Sektor Unggulan dan Kinerja Ekonomi Provinsi Jawa Barat. Skripsi. Bogor: Institut Pertanian Bogor (IPB).

Direktorat Jenderal Perekebunan .2014. Statistik Perkebunan Indonesia 2014-2016: Kopi (Coffee). Jakarta: Direktorat Jenderal Perkebunan (Directorate General of Eastate Crops).

Dinas Pertanian dan Perkebunan Kabupaten Kerinci, Propinsi Jambi .2016. Produks Domestik Regional Bruto Kabupaten Kerinci. Kerinci: Badan Pusat Statistik Kabupaten Kerinci.

Dinas Perkebunan Provinsi Jambi, 2018. Statistik Perkebunan Provinsi Jambi. Jambi: Dinas Perkebunan Provinsi Jambi.

Ida Ayu Listia Dewi dan I Made Sudarma, 2020. Faktor-Faktor Pendukung Keberlanjutan Usahatani Kopi Arabika di Provinsi Bali. SOCA: Jurnal Sosial Ekonomi Pertanian. Vol. 14 No. 1, 31 Januari 2020, page 158 - 168. ISSN: 2615-6628 (E), ISSN: 1411-7177 (P)

International Coffee Organization, 2019. World Coffee Statistics. International Coffee Organization. 22 Gray's Inn Road, London WC1X8HB, Email: web@ico.org. www.ico.org .

Joachim, R., Dan, A., \& Djuwendah, E. (2018). Analisis Pendapatan Usahatani Kopi Java Preanger Kecamatan Pengalengan Bandung Analysis of Java Preanger Coffee Farmers Income At Margamulya Farmers Group in Margamulya Village Pangalengan Sub-District Bandung Regency. 6, 31-38.

Kementerian Pertanian Republik Indonesia. 2018. Kementan Dukung Kabupeten Kerinci Jadi Kopi Andalan Berbasis Agrowisata, [Internet] [Diaplot tgl, 29 Januari 2020]. Tersedia dari https: / / www.pertanian.go.id/home/?show=news\&act=view\&id=3529.

Lina Marlina, Arya Hadi Dharmawan, Yetti Lis Purnamadewi, 2017. Peranan Kopi Rakyat Terhadap Perekonomian Wilayah Kabupaten Lampung Barat. JIIA, VOLUME 5 No. 3, Periode AGUSTUS 2017. page:292-303. 
Ni Wayan Rainy Priadarsini Sukiada dan Anak Agung Ayu Intan Parameswari, 2020. Nation Branding Kopi Arabika Kintamani (Studi Kasus: Kopi Gunung Catur, Desa Catur, Kintamani, Bangli). SOCA: Jurnal Sosial Ekonomi Pertanian, Vol. 14 No. 1, 31 Januari 2020, ISSN: 2615-6628 (E), ISSN: 1411-7177 (P). page $180-193$.

Pemerintah Daerah Provinsi Jambi, 2018. Jambi Daerah Potensial Tiga Jenis Kopi. Sekretaris Daerah Provinsi Jambi, [Diaplot tgl, 29 Januari 2020]. Tersedia dari http:/ /jambiprov.go.id/v2/berita-sekda-jambi-daerah-potensial-tiga-jeniskopi-.htm.

Panggabean, Edy, 2011. Buku Pintar KOPI. Jakarta: Agromedia Pustaka.

Rakotonjanahary Joachim Audry, Dan Endah Djuwendah, 2018. Analisis Pendapatan Usahatani Kopi Java Preanger Pada Kelompok Tani Margamulya Desa Margamulya Kecamatan Pengalengan Bandung. Jurnal Ilmu Pertanian dan Peternakan Volume 6 Nomor 1 Juli 2018. page:31-38

Suandi, Herlinda, Yusma Damayanti, Herlina, Tenisiah, dan Dela Nofela, 2013. Kajian Prospek Penanaman Kopi Arabika Di Kabupaten Kerinci. Laporan Penelitian (tidak dipublikasikan) Kerjasama Universitas Jambi dengan Badan Perencanaan Pembangunan Daerah (BAPPEDA) Kabupaten Kerinci. Kerinci: Badan Perencanaan Pembangunan Daerah (BAPPEDA) Kabupaten Kerinci.

Sukirno, Sadono, 2011. Ekonomi Pembangunan: Proses ,Masalah, dan Dasar Kebijakan. Jakarta: Kencana Prenada Media Group.

Sugiyanto, \& Sukesi. (2010). Penelitian Pengembangan Pusat-Pusat Pertumbuhan Ekonomi di Kabupaten Lamandau. Jurnal Mitra Ekonomi Dan Manajemen Bisnis, 1(2), 202-215.

Syahyuti. 2007. Kebijakan Pengembangan Gabungan Kelompok Tani (Gapoktan) sebagai Kelembagaan Ekonomi di Perdesaan: Analisis Kebijakan Pertanian. Jurnal Pertanian 5(2):15-35.

Tarigan Robinson. 2012. Ekonomi Regional: Teori dan Aplikasi. Edisi Revisi. Jakarta: Bumi Aksara. 